\title{
Induction of apoptosis by all-trans retinoic acid in the human myeloma cell line RPMI 8226 and negative regulation of some of its typical morphological features by dexamethasone
}

Olga Lefebvre ${ }^{1}$, Danièle Wouters ${ }^{1}$, Claude Méreau-Richard ${ }^{1}$, Thierry Facon ${ }^{1,2}$, Marc Zandecki ${ }^{3}$, Pierre Formstecher ${ }^{\star, 1}$ and Marie-Thérèse Belin ${ }^{1}$

${ }^{1}$ Laboratoire de Biologie Cellulaire, INSERM U459, Faculté de Médecine, 1 , Place de Verdun, 59045 Lille Cedex, France

2 Service des Maladies du Sang, Hôpital Huriez, $\mathrm{CH}$ et $\mathrm{U}$ de Lille, Place de Verdun, 59037 Lille Cedex, France

${ }^{3}$ Laboratoire d'Hématologie, Hôpital Calmette, $\mathrm{CH}$ et U de Lille, Bd du Pr. Leclercq, 59037 Lille Cedex, France

* corresponding author: P. Formstecher, Laboratoire de Biologie Cellulaire, INSERM U459, Faculté de Médecine, 1, Place de Verdun, 59045, Lille Cedex, France. tel: 3303206269 52; fax: 3303206268 84;

e-mail formstecher@lille.inserm.fr

Received 15.12.97; revised 15.10.98; accepted 12.2.99

Edited by J.C. Ameisen

\begin{abstract}
We investigated the effects of all-trans retinoic acid (RA) and dexamethasone (Dex) on the in vitro growth of the human myeloma cell line RPMI 8226. RA inhibited RPMI 8226 cell growth by both antiproliferative effect and induction of apoptosis. Typical morphological and biochemical characteristics of apoptosis including chromatin condensation, apoptotic bodies formation and internucleosomal DNA cleavage were detected after 4 days of treatment with $1 \mu \mathrm{M}$ RA. In situ TUNEL assay demonstrated that DNA cleavage preceded chromatin condensation. The expression of tissue transglutaminase (tTG), an enzyme proposed to play a role in apoptosis was induced with RA, as shown by both enzymatic assay and in situ immunofluorescence detection. Dex, when used alone, had no effect on cell growth and apoptosis. When combined to RA, Dex did not interfere with the RA-dependent inhibition of cell proliferation, but unexpectedly inhibited both quantitatively and qualitatively several morphological and biochemical features of the apoptosis induced by RA. Dex did not affect RA-induced DNA breaks formation but impeded the progression of chromatin condensation and the formation of apoptotic bodies. Interestingly, Dex also inhibited the RAdependent induction of tTG. RU486, a glucocorticoid antagonist, counteracted all Dex effects. Taken together these data demonstrate that key cytoplasmic and nuclear events occurring during apoptosis are differentially regulated by $\mathrm{RA}$ and Dex in myeloma cell line RPMI 8226.
\end{abstract}

Keywords: apoptosis; dexamethasone; retinoic acid; myeloma; tissue transglutaminase
Abbreviations: RA, all-trans retinoic acid; Dex, dexamethasone; tTG, tissue transglutaminase; CAM, camptothecin; MGG, May Grünwald Giemsa; TUNEL, Terminal deoxynucleotidyl transferase (TdT)-mediated dUTP-biotin nick end labeling; IL-6, interleukin-6; DMSO, dimethylsulfoxide; DABCO, 1,4-diazabicyclo(2,2,2)octane); TCA, trichloroacetic acid

\section{Introduction}

Multiple myeloma remains an incurable malignancy. None of the recent advances in chemotherapy resulted in decisive improvement in the prognosis of the disease and new therapeutic approaches are needed. ${ }^{1}$

Retinoids are well known regulators of cell proliferation, cell differentiation and embryonal development. ${ }^{2,3}$ Their potential use for cancer treatment received a renewed interest since the successful introduction of RA as therapy for acute promyelocytic leukemia, and significant clinical responses have also been observed in other malignancies. ${ }^{4,5}$ Sidell et $a l^{6}$ have reported an inhibitory effect of RA on the growth of a human myeloma cell line, AF-10, via downregulation of IL-6 receptors. This observation was further documented by in vitro studies on fresh human myelomatous plasma cells. ${ }^{7}$ RA was also reported to inhibit growth of myeloma cells via a mechanism distinct from IL-6 modulation. ${ }^{8}$ Cell accumulation in cancer can result from either increase in proliferation or failure of cells to undergo apoptosis: ${ }^{9}$ RA has been reported to inhibit the proliferation of various cancer cell lines, ${ }^{5,10}$ but also to induce apoptosis in several models, including HL-60 human leukemia cells. ${ }^{11-14}$

Dex is one of the most effective agents in myeloma therapy: ${ }^{15}$ however, there are conflicting data about its effects on myeloma cells growth. ${ }^{16,17}$

In this study we investigated the effects of RA and Dex on both proliferation and cell death of a human myeloma cell line, RPMI 8226. ${ }^{18}$ RA was demonstrated to induce typical apoptosis in these cells. The expression of several morphological and biochemical features of this apoptosis was surprisingly inhibited in the presence of Dex.

\section{Results}

\section{Inhibition of cell growth}

The effects of RA, Dex and RU486, an antiglucocorticoid, on the growth of RPMI 8226 cells were evaluated (Figure 1). Treatment with $1 \mu \mathrm{M}$ RA alone resulted in significant slowing down of cell growth observable from the second day and leading to a progressive growth arrest which was almost 
complete after 6 days. RPMI 8226 cells appeared unresponsive to glucocorticoids, since Dex and RU486 treated cells grew as control cells. Dex had no effect on the growth inhibition induced by RA.

\section{Antiproliferative effect}

To document the antiproliferative effect of RA, the rate of DNA synthesis was evaluated. As shown in Figure 2, an inhibitory effect of RA was also evident in $\left[{ }^{3} \mathrm{H}\right]$ thymidine incorporation of RPMI 8226 cells: RA suppressed $\left[{ }^{3} \mathrm{H}\right.$ ]thymidine uptake by approximately $75 \%$ and neither combination of RA and Dex nor RA+Dex+RU486 modified this effect. Dex and RU486, used alone, were here again ineffective. This result was confirmed by determining the growing fraction of the cell population by using Ki-67 antibody. This antibody reacts with an antigen expressed in all stages of the cell cycle with the exception of G0. In control cells, the percentage of $\mathrm{Ki}-67$ positive cells, evaluated after a 3 days culture was $80 \%$ $( \pm 7.6)$ and did not change during the next 2 days. In RA treated cells, the percentage was $36 \%( \pm 7.6)$ after a 3 days treatment and decreased to $17 \%( \pm 2.1)$ after 4 days (not shown). DNA synthesis arrest is an earlier event when compared to the decrease of the number in Ki-67 positive cells, since suppression of $\left[{ }^{3} \mathrm{H}\right]$ thymidine uptake was effective after a $48 \mathrm{~h}$ treatment while decrease in Ki-67 positive cells was observed after 3 days. It has been already demonstrated that Ki-67 antigen expression can persist $24 \mathrm{~h}$ after cell cycle arrest. $^{19}$

\section{Induction of apoptosis}

To investigate whether RA-induced inhibition of cell growth was also due to cell death, cell morphology was observed after MGG (May-Grünwald Giemsa) and Hoechst 33258 staining. Cells treated with $1 \mu \mathrm{M}$ RA showed typical

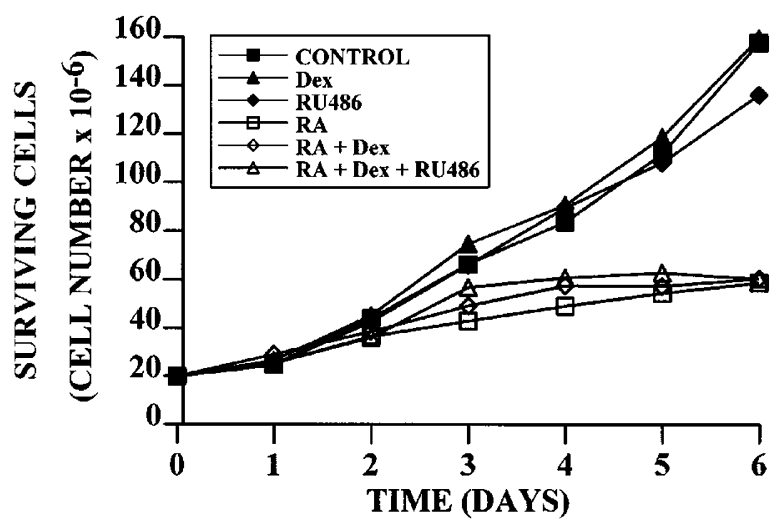

Figure 1 Effects of RA, Dex and RU486, an antiglucocorticoid, on RPMI 8226 cells growth. Cell proliferation was evaluated by direct counting (Trypan blue method). Cells were cultured for 2 days with a single dose of each specified compound (RA $1 \mu \mathrm{M}$, Dex $0.5 \mu \mathrm{M}$ and RU486 $2 \mu \mathrm{M}$ ) used alone or in combination. After 2 days, the medium was supplemented to $10 \%$ FCS and cells were further incubated for 4 days at $37^{\circ} \mathrm{C}$. Living cells were counted daily. Mean values $(n=6)$ are shown plotted against time. Differences between RAand not RA-treated cells were highly significant after day $3(P=0.0017$ at day 3 and $<0.0001$ at day 6 ) morphological features of apoptosis (Figures 3B and 4B). $20.6 \%( \pm 4.5)$ of RA-treated cells were apoptotic, contrasting with less than $0.9 \%( \pm 0.5)$ for control cells (Figure 5$)$. Dex and RU486 alone did not induce any apoptotic change (results within values of controls). However when used in combination with RA, Dex inhibited the RA-dependent induction of key morphological changes related to apoptosis (Figures 3-5). When compared to RA-treated cells, cells treated with the combination of RA and Dex were characterized by a striking decrease of the number of cells showing typical apoptotic features, and a strong inhibition of apoptotic bodies formation. However, vacuolisation of the cytoplasm, a common feature of apoptotic cells, was observed in cells treated with RA+Dex. Moreover in most cells the nucleus was looking different from control cells as it appeared partially condensed and fragmented (Figures $3 \mathrm{C}$ and 4C). Interestingly these effects of Dex could be counteracted by RU486, which restored the classical morphology of apoptosis induced by RA (Figures 3D and 4D), and were therefore probably mediated by the glucocorticoid receptor.

\section{DNA fragmentation}

To ascertain that RA induced apoptosis in RPMI 8226 cells, treated cells were submitted to qualitative analysis of DNA fragmentation. We used a new very sensitive and semiquantitative ligation-mediated PCR assay for the detection of DNA breaks. ${ }^{20}$ A typical DNA ladder was observed after treatment with RA (Figure 6A, lane 2), or with RA+Dex or $\mathrm{RA}+\mathrm{Dex}+\mathrm{RU} 486$ (lanes 3 and 4), whereas after treatment with Dex or RU 486 alone a very faint ladder was obtained

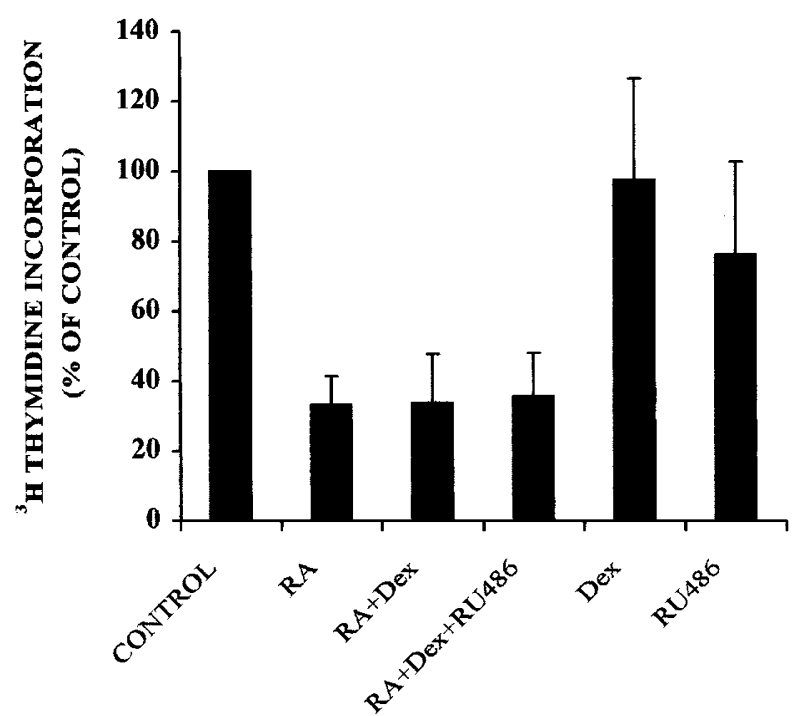

Figure 2 Effects of RA, Dex, and RU486 on the rate of DNA synthesis. RPMI 8226 cells were incubated in the absence (control) or in the presence of the indicated compounds, used at the same concentration as in Figure 3. $\left[{ }^{3} \mathrm{H}\right]$ thymidine incorporation was performed at $48 \mathrm{~h}$ for $3 \mathrm{~h}$, as described in Materials and Methods. Data are expressed as the mean \pm S.D. $(n=5)$ percentages of c.p.m. incorporated in cells treated with inducing agents versus control. Differences between RA- and not RA-treated samples were highly statistically significant $(P<0.0004)$ 

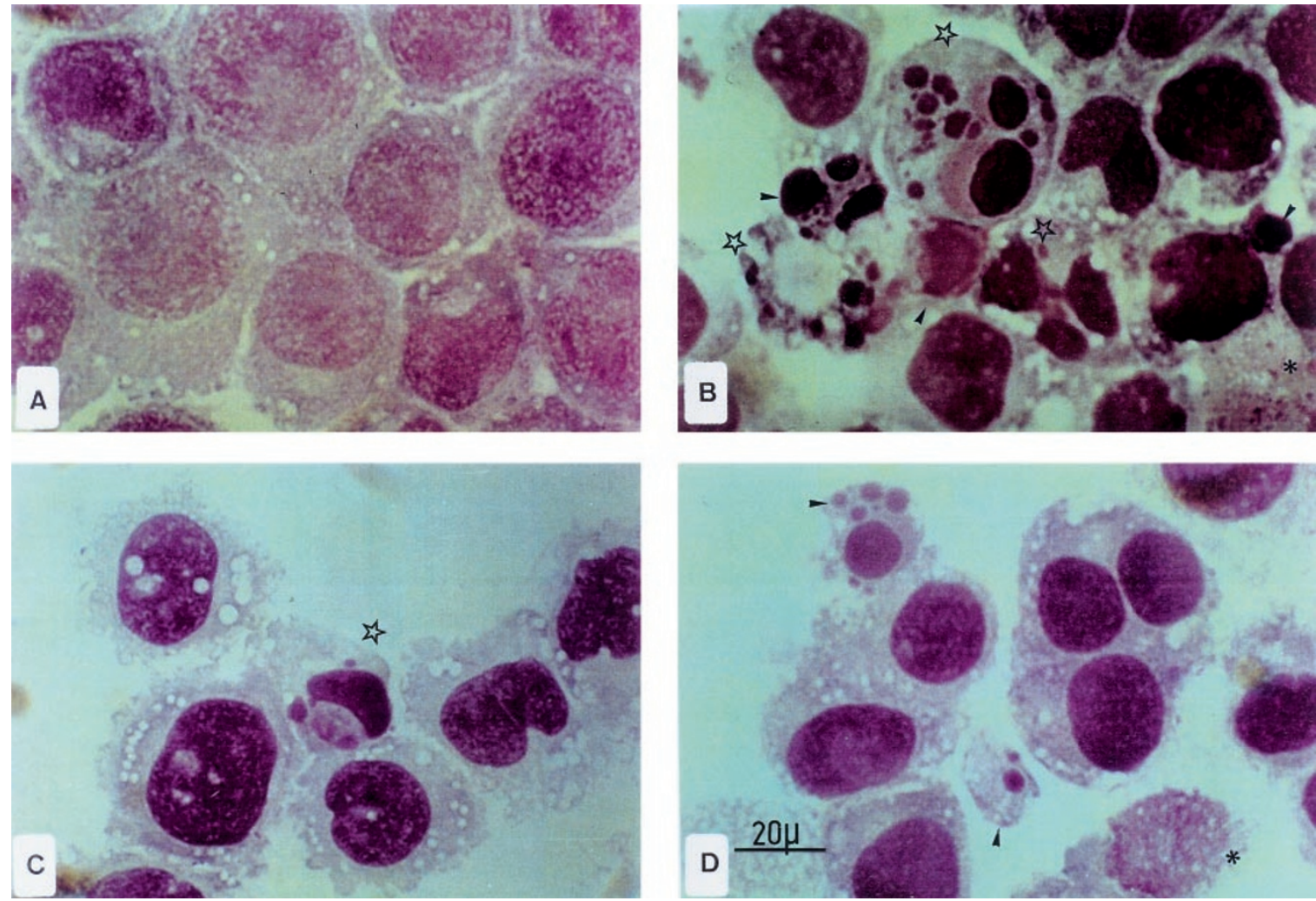

Figure 3 Morphologic aspect of RPMI 8226 after treatment with RA. Cells were analyzed by May-Grünwald Giemsa staining at day 6 post induction (magnification $\times 1000)$. (A) untreated cells, (B) cells treated with RA $(1 \mu \mathrm{M})$ alone, $(\mathbf{C})$ with RA $(1 \mu \mathrm{M})$ plus Dex $(0.5 \mu \mathrm{M})$ or $(\mathbf{D})$ with RA $(1 \mu \mathrm{M})$ plus Dex $(0.5 \mu \mathrm{M})$ and RU486 $(2 \mu \mathrm{M})$. Typical apoptotic cells ( $\left(\begin{array}{c}\mathrm{j}) \\ )\end{array}\right)$ apoptotic bodies (arrowheads) and atypical apoptotic cells $(\star)$ are indicated. There was no morphological change in cells treated with Dex or RU486 alone (data not shown)

(lanes 5 and 6). The RA-induced DNA fragmentation was also evaluated by a quantitative assay of the low molecular weight DNA extracted from the lysed cells (Figure 6B). $10.1 \pm 2 \%$ of fragmented DNA was found in RA-treated cells and only $0.5 \%$ in untreated cells. For cells treated with $R A+D e x$ and $R A+D e x+R U 486$, values were $8 \pm 1.8$ and $8 \pm 1.6 \%$ respectively. Treatment with Dex or RU 486 alone resulted in a very small, but significant, increase in low molecular weight DNA. Taken together these data indicate that RA induces true DNA fragmentation in RPMI 8226 cells. This phenomenon was not inhibited by Dex treatment contrary to the condensation of chromatin and fragmentation of nuclei observed on MGG or Hoechst stained cytospin cell preparations. Finally the TUNEL method provided more details on this puzzling observation by allowing in situ labeling of DNA breaks (Figure 7). RA-treated cells showed a high level of DNA fragmentation in the condensed and fragmented chromatin. In cells treated with RA+Dex, a more diffuse labeling was observed in a significant number of cells where no typical chromatin condensation and nuclear fragmentation could be observed by MGG or Hoechst staining. These data demonstrated that Dex did not inhibit the RA-induced DNA breaks formation and the beginning of chromatin condensation, but impeded the progression of this condensation followed by the fragmentation of nuclei and the formation of apoptotic bodies.

\section{Induction of tissue transglutaminase}

TTG has been suggested to be implicated in the formation of apoptotic bodies. ${ }^{21}$ Induction of both enzymatic activity and expression of the protein was studied in RA-treated cells. As shown in Figure 8, the basal level of tTG activity in untreated cells was extremely low and treatment with $1 \mu \mathrm{M}$ RA for $48 \mathrm{~h}$ resulted in striking induction of this activity. Dex produced a strong inhibition of this induction, an effect prevented by the addition of RU486. Immunofluorescence studies (Figure 9) demonstrated a very low expression of the protein in untreated cells, whereas a very strong expression was found in RA-treated cells, with the strongest reactivity within apoptotic bodies. This effect was inhibited by Dex and as a rule restored by adding $R U 486$. Taken together these results suggested that Dex downregulated TTG induction through ligand activation of the glucocorticoid receptor.

\section{Flow cytometric analysis}

In order to delineate more accurately the relative contribution of the cell cycle arrest and cell death induced by RA, flow cytometric analysis was used. RPMI 8226 cells were analyzed for DNA content after propidium iodide staining (Figure 10). The kinetics of the repartition of cells in the various phases of the cell cycle were modified by RA 

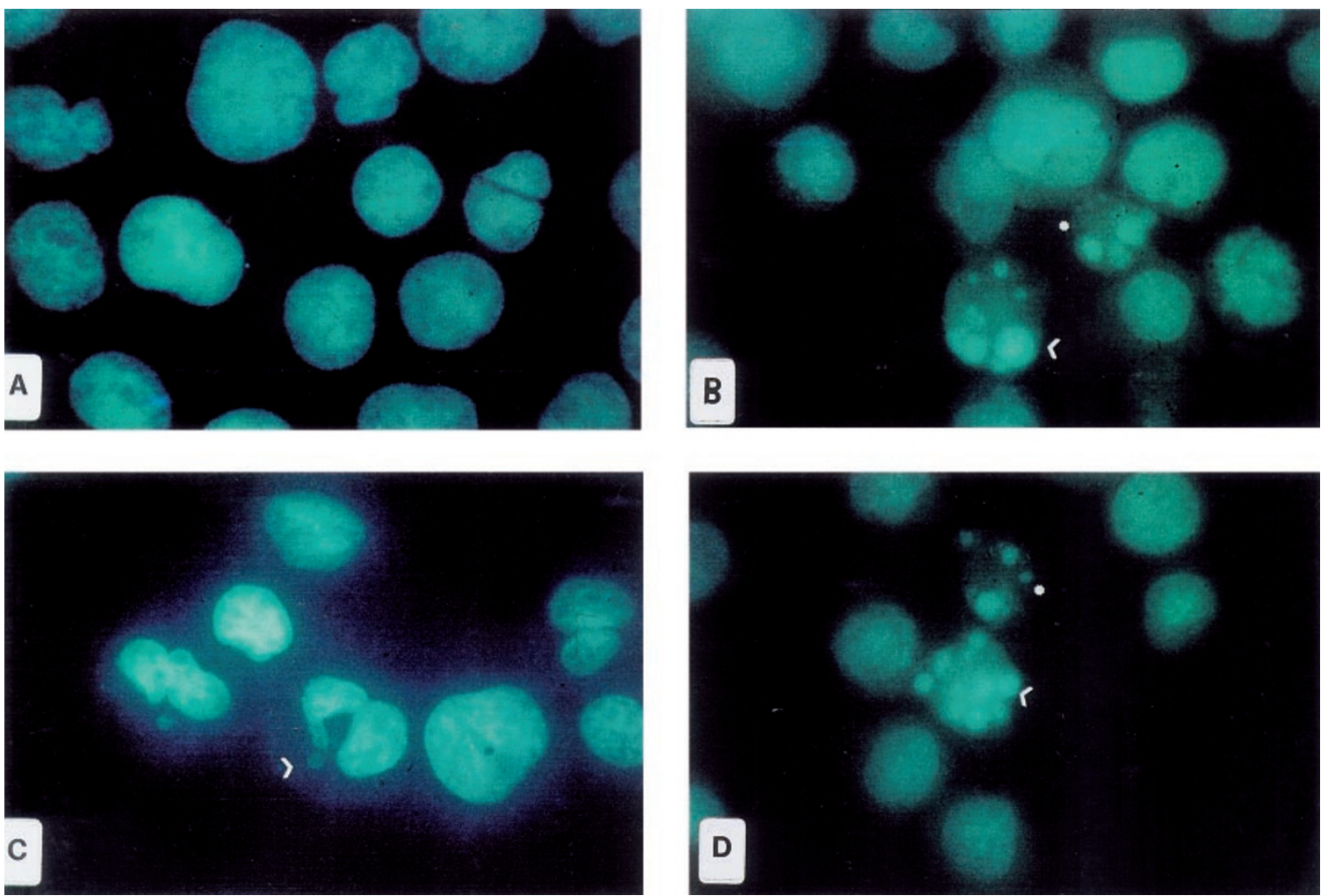

Figure 4 Hoechst 33258 staining of RPMI 8226 cells nuclei. Untreated cells (A) and cells treated with either RA (B), RA plus Dex (C) or RA plus Dex and RU486

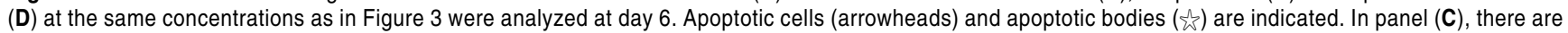
no apoptotic bodies; only one cell displays typical apoptosis and other cells display atypical apoptosis with presence of DNA in the cytoplasm

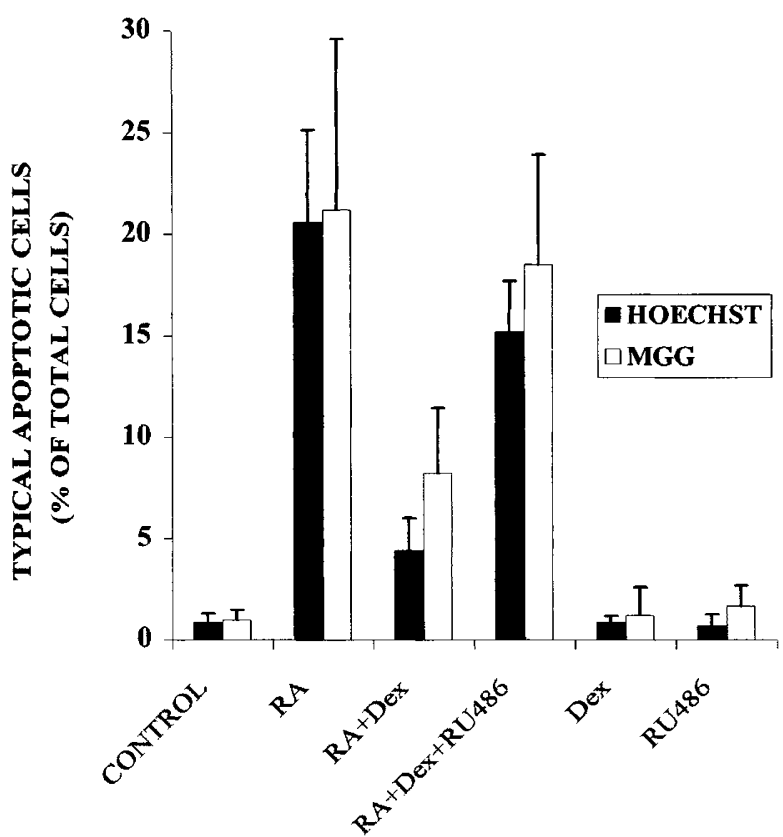

Figure 5 Quantification of apoptotic cells after treatment with RA and/or Dex and RU486. RPMI 8226 cells treated as described in Figure 4 were stained either by Hoechst 33258 (HOECHST) or by May-Grünwald Giemsa (MGG). In each case the percentage of apoptotic cells was determined in duplicate counts of 400 cells. Mean values \pm S.D. from six independent experiments are shown treatment. The percentage of cells in G0/G1 increased at J2 and $\mathrm{J} 3$, with a decrease in cells in the $\mathrm{S}$ and G2/M phases, whereas the percentage of cells in sub-G0/G1 increased slightly at $\mathrm{J} 2$ and $\mathrm{J} 3$ and more strongly between $\mathrm{J} 4$ and $\mathrm{J} 6$ (Figures 10 and 11A). Dex and RU 486 apparently did not modify the response to RA, and here again were inactive when used alone. These data are in accordance with the $\left[{ }^{3} \mathrm{H}\right]$ thymidine incorporation assay. RA inhibits the progression of the cells from $\mathrm{G} 1$ to $\mathrm{S}$. Cells accumulate first in G0/G1 and then in sub-G0/G1 and die. Interestingly, RA-induced apoptosis has been reported to be preceded by $\mathrm{G} 1$ arrest in human MCF-7 breast cancer cells. ${ }^{22}$ Sub-G0/G1 cells have lost a significant part of their DNA. The percentage of cells with typical or atypical morphological apoptotic features was determined after 6 days of treatment (Figure 11B and C). The total of dying and dead cells is in each case in good agreement with the percentage of sub-G0/G1 cells measured by flow cytometry (Figure 11A). Interestingly, the amount of dying cells was the same in samples treated with RA or RA plus Dex. However, their way to die was different. Treatment with RA resulted in death through typical apoptosis, whereas in the presence of Dex, death was atypical, without nuclear fragmentation or apoptotic bodies.

\section{Discussion}

We demonstrated here that RA modulates RPMI 8226 cell growth by both inhibiting cell proliferation and inducing 


\section{A}

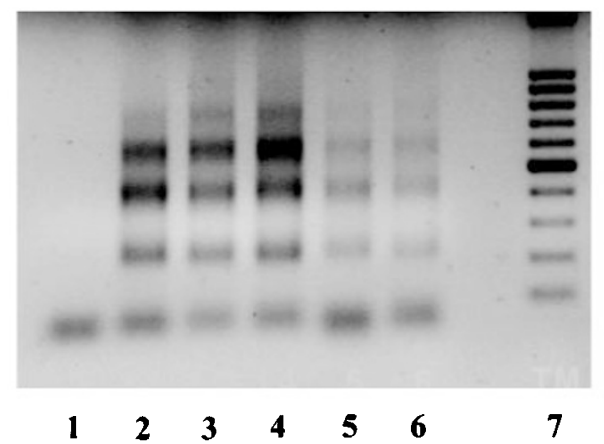

B

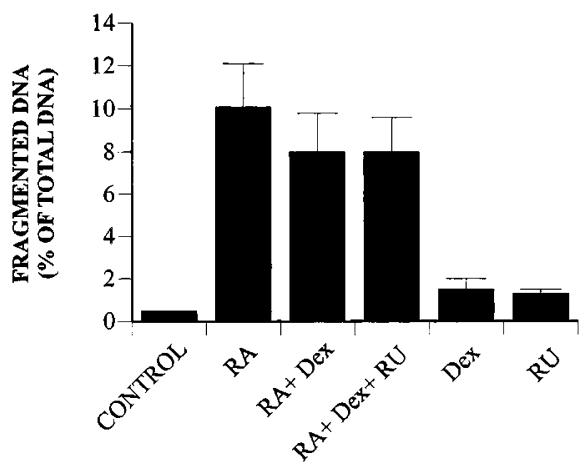

Figure 6 DNA fragmentation analysis. (A) Analysis by gel electrophoresis. RA-induced nucleosomal ladders were visualized after LM-PCR assay as described in Materials and Methods. Human myeloma cells were either untreated (lane 1) or treated for 5 days with $1 \mu \mathrm{M} \mathrm{RA}$ (lane 2), $0.5 \mu \mathrm{M}$ Dex (lane 5) or $2 \mu \mathrm{M}$ RU486 (lane 6). RA was also used in combination with Dex or Dex plus RU486 (lanes 3 and 4). Lane 7 represents the size marker ( $\times 100 \mathrm{bp}$ ). Because of the addition of the adaptors ( $48 \mathrm{bp}$ total), the bands are slightly larger than those of a conventional ladder. (B) Quantification of fragmented DNA by the diphenylamine assay as described in Materials and Methods. Results are expressed as the percentage of total DNA from $2 \times 10^{7}$ cells

apoptosis. Surprisingly, an inhibition of the induction of some typical features of apoptosis was observed when Dex was combined to RA.

Conflicting data have been reported about the effect of RA on RPMI 8226 cell growth, some authors observing a clear inhibition of cell proliferation ${ }^{23-25}$ whereas others found no effect. ${ }^{26}$ We have no clear explanation for these discrepancies which are probably due to the use of different RPMI 8226 subclones. It has been recently reported that according to the passage number, cancer cells could display divergent response to retinoids and steroids. ${ }^{27}$ The mechanism by which RA inhibits myeloma cell growth is still not clearly understood. In IL-6 dependent myeloma cell lines, and in myeloma cells freshly isolated from patients, RA has been shown to downregulate IL-6 receptor expression, and was identified as a negative modulator of the IL-6 mediated autocrine/paracrine growth. $6,7,25,26$ However RA has also been reported to inhibit the growth of IL- 6 independent myeloma cell lines. ${ }^{8}$ In fact the mechanisms by which retinoids negatively regulate tumor cell growth are largely unknown. A better understanding of these mechanisms will require the characterization of the subtype of receptor involved, RAR and/or $\mathrm{RXR},{ }^{28}$ and the identification of the target genes involved. Preliminary results from our laboratory suggest that the activation of both RAR and RXR is required to obtain a full response on cell proliferation and apoptosis. ${ }^{29}$

We did not observe any effect of Dex alone on RPMI 8226 cell growth. Our data are in agreement with previous papers reporting that RPMI 8226 cell growth was insensitive to glucocorticoids. ${ }^{16,26}$ This resistance was attributed to a post-receptor mechanism, since the presence of a functional glucocorticoid receptor was documented in these cells. ${ }^{16}$ This result is in accordance with our findings that Dex, despite its lack of effect on RPMI 8226 cell growth, was still able to modulate RAdependent induction of apoptosis and tTG in these cells. These responses were likely mediated by the glucocorticoid receptor, as suggested by the inhibitory effect of RU486, an antiglucocorticoid acting at the receptor level. Very recently RPMI 8226 cells have been reported to be sensitive to Dex, which inhibited cell growth at low concentrations and induced apoptosis at high (micromolar) concentrations. ${ }^{30,31}$ In a congress abstract, a synergy between RA and Dex has been reported, ${ }^{8}$ in sharp contrast with other reports describing RPMI 8226 as resistant to both agents. ${ }^{26}$ This discrepancy with previous results could also be due to the use of different RPMI 8226 subclones. If glucocorticoids are among the most effective agents in treating myeloma and inhibit the proliferation of myeloma cells freshly purified from bone marrow aspirates, ${ }^{17}$ their effects on myeloma cell lines in culture are far more variable. ${ }^{16,30-33}$ In fact myeloma cells become progressively resistant to glucocorticoids either by acquiring a glucocorticoid receptor mutation $^{34}$ or more commonly by a post-receptor mechanism. ${ }^{16}$ The latter mechanism could affect the expression of only a subset of the different genes normally controlled by glucocorticoids in the fully sensitive cell lines and explain why some other cell lines exhibit dissociated or incomplete responses to glucocorticoid treatment.

Our results demonstrated clearly that RA is able to induce apoptosis in RPMI 8226 cells. Typical morphological and biochemical characteristics of apoptosis ${ }^{35}$ were observed. When compared to the inhibition of cell proliferation the kinetic of induction of apoptosis appeared slower. Typical apoptotic cells were detected by MGG and Hoechst staining after 4 days of RA treatment. However with the more sensitive TUNEL assay DNA cleavage was already observable in situ after 3 days. DNA cleavage has already been demonstrated to occur before chromatin 

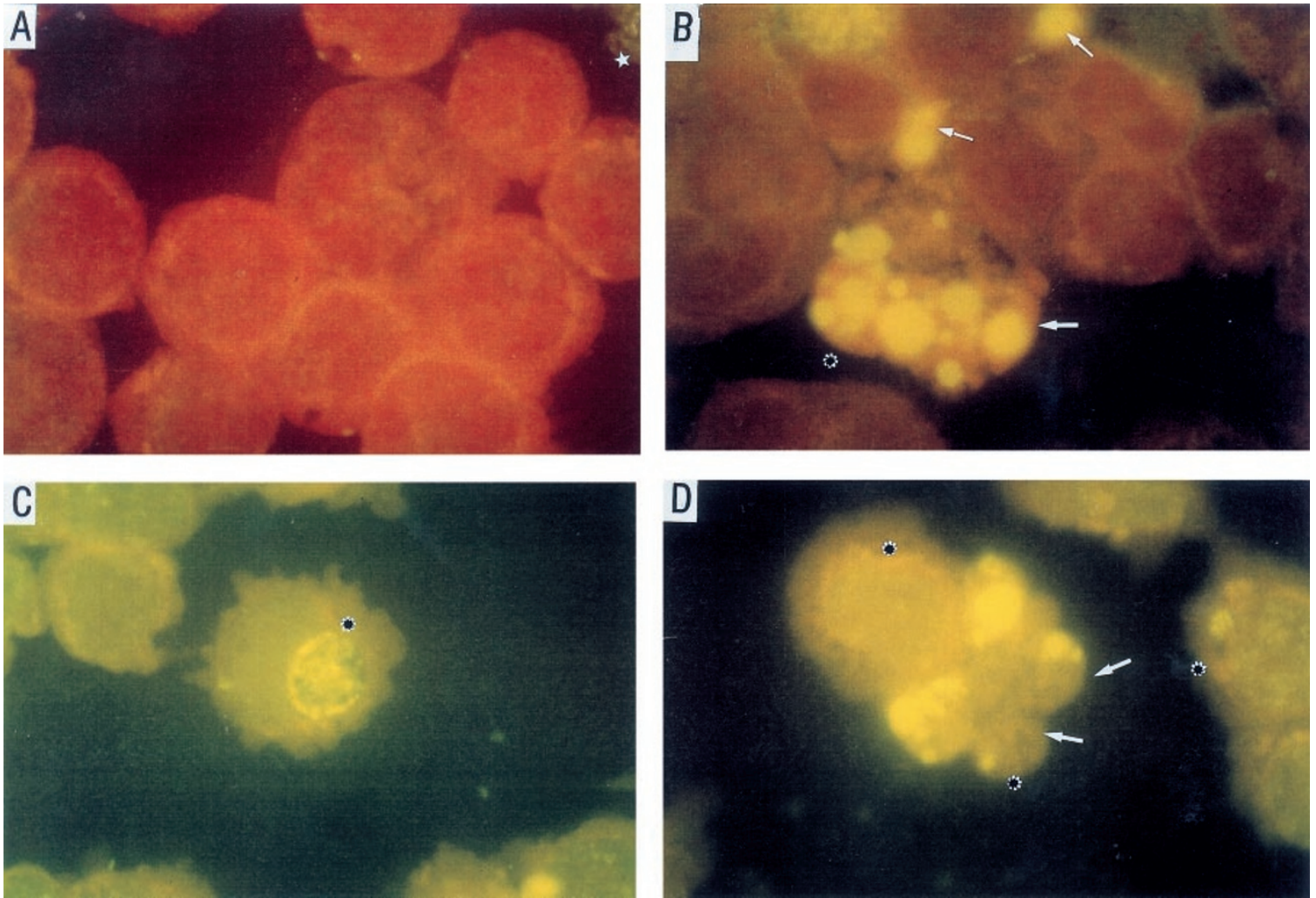

Figure 7 In situ labeling of DNA strand breaks. Untreated cells (A) and cells treated with either RA (B), RA plus Dex (C) or RA plus Dex and RU486 (D) at the same concentrations as in Figure 4 were analyzed at day 6 using the TUNEL assay as described in Material and Methods. Apoptotic cells ( $\star$ ) and apoptotic bodies (arrows) are indicated

A)

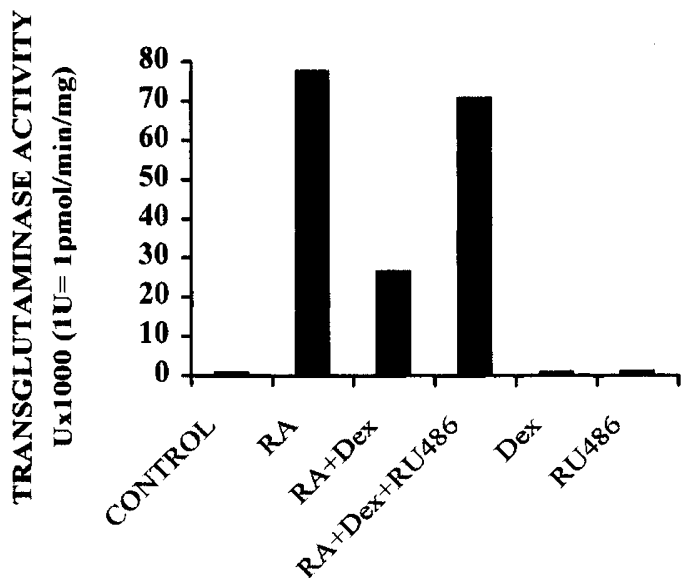

B)

\begin{tabular}{|c|c|c|}
\hline SAMPLES $(\mathrm{n}=5)$ & \%RA & SD \\
\hline CONTROL & 0,6 & 1,2 \\
\hline RA & 100 & 0 \\
\hline RA+Dex & 31,8 & 8,2 \\
\hline RA+Dex+RU486 & 82,2 & 8,6 \\
\hline Dex & 1 & 1,4 \\
\hline RU486 & 1,2 & 1,5 \\
\hline
\end{tabular}

Figure 8 Tissue transglutaminase activity in RPMI 8226 cells treated with RA, Dex or RU486. Specific tTG activity ( $1 \mathrm{U}=1 \mathrm{pm}$ of $\left[{ }^{3} \mathrm{H}\right]$ putrescin incorporated in NN' methylcasein/min/mg of cell proteins at $30^{\circ} \mathrm{C}$ ) was analyzed in cells treated for $48 \mathrm{~h}$ with the same concentrations and combinations of agents as in the preceding figures. (A) results of a representative experiment, (B) mean of five different experiments. Results are expressed as a percentage of tTG activity detected after treatment with $1 \mu \mathrm{M}$ RA. Differences between RA- and RA+Dex-treated samples were highly significant $(P=0.0006)$ 
condensation in other models. ${ }^{36}$ RPMI 8826 cells treated with both RA and Dex failed to show any typical chromatin condensation, whereas DNA breaks were detected by both TUNEL assay and DNA electrophoresis, suggesting that these two phenomenons were independently regulated in our cells. It has been reported that morphological changes typical of apoptosis, like chromatin condensation, could be dissociated from internucleosomal cleavage ${ }^{37}$ and the role played by DNA fragmentation in the apoptotic process is presently controversial. ${ }^{38}$ Chromatin condensation during
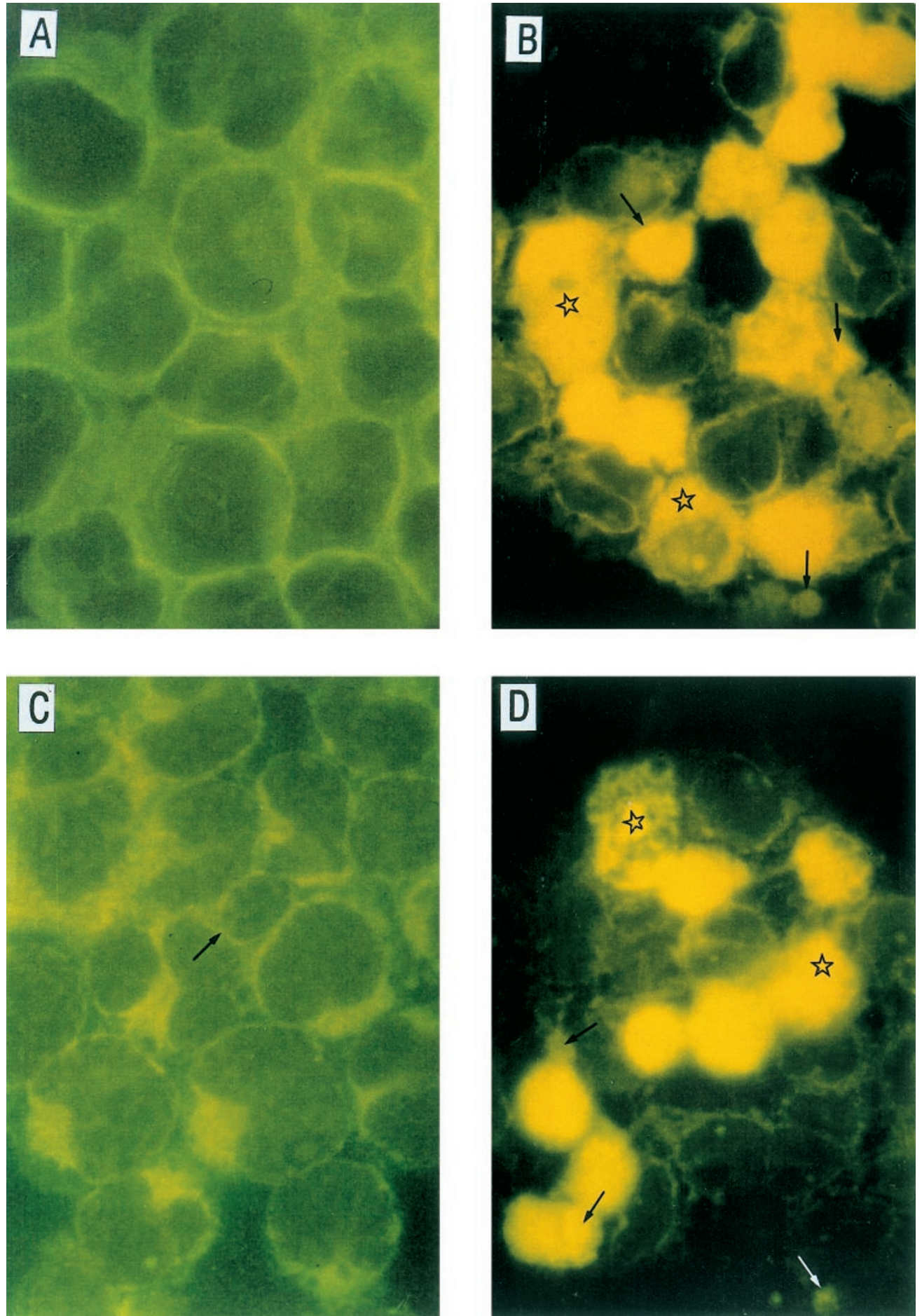

Figure 9 Indirect immunofluorescence detection of tissue transglutaminase in RPMI 8226. Untreated cells (A) and cells treated with either $1 \mu \mathrm{M}$ RA (B) or $1 \mu \mathrm{M}$ RA plus $0.5 \mu \mathrm{M}$ Dex (C) or $1 \mu \mathrm{M}$ RA plus $0.5 \mu \mathrm{M}$ Dex and $2 \mu \mathrm{M}$ RU486 (D) were analyzed after 6 days of culture (magnification $\times 1000$ ). Cells treated with Dex or RU486 alone gave results similar to untreated cells (data not shown). Apoptotic cells (it) and apoptotic bodies (arrows) are indicated 


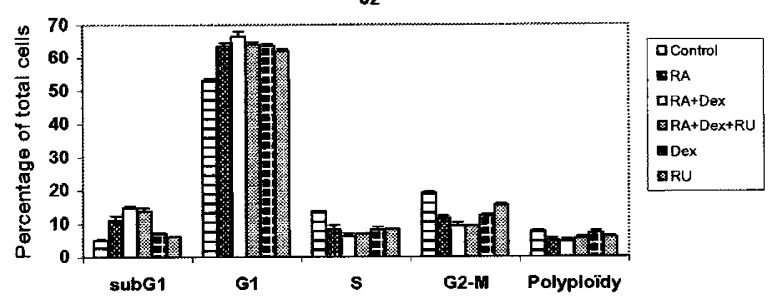

J3
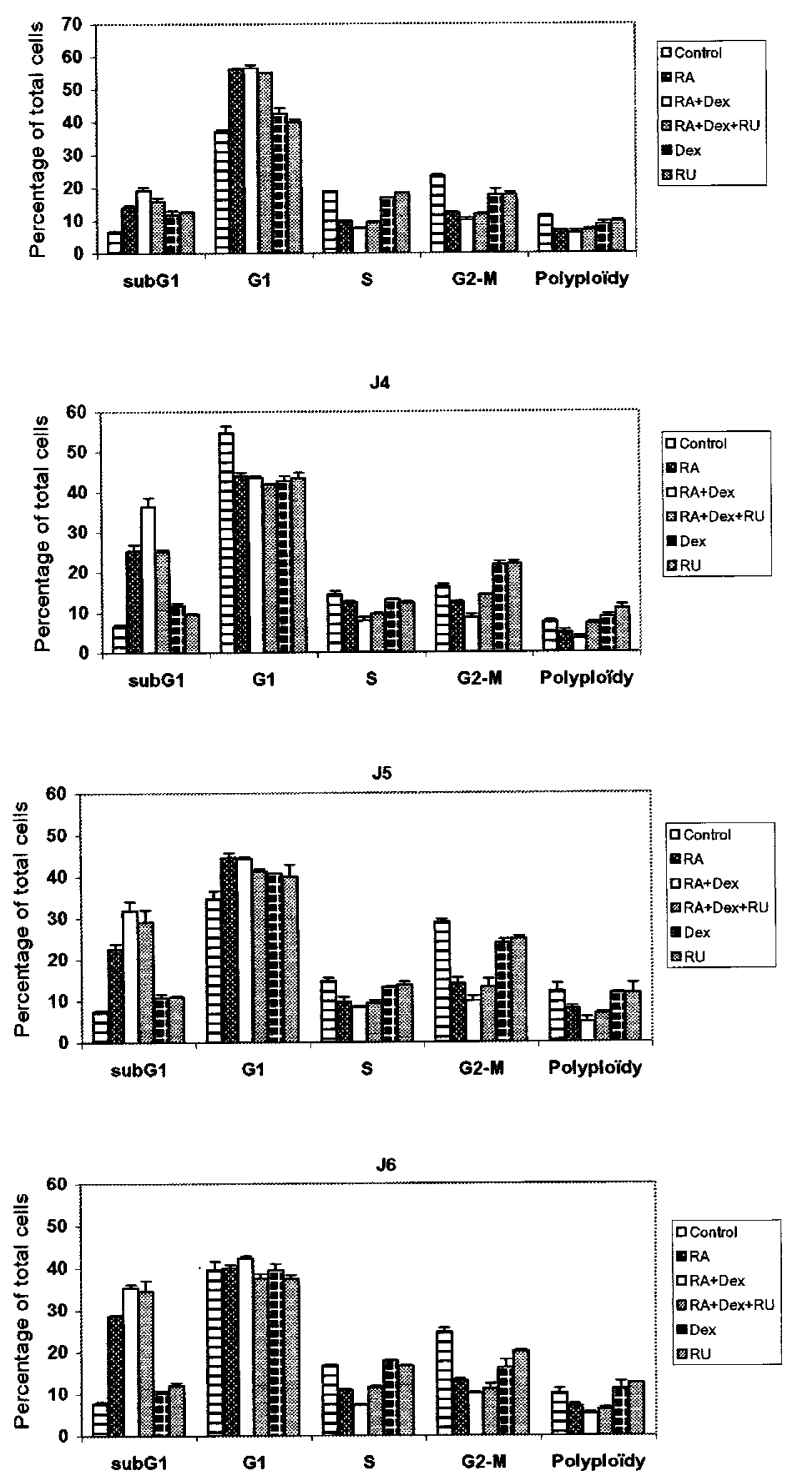

Figure 10 Kinetics of the effects of RA and Dex on the cell cycle paramters. RPMI 8226 cells were cultured for 6 days after treatment with $1 \mu \mathrm{M}$ RA, $0.5 \mu \mathrm{M}$ Dex or $2 \mu \mathrm{M}$ RU486 used alone or in combination. Flow cytometry DNA histograms after propidium iodide staining were recorded and analyzed. The percentage of cells in the various phases of the cell cycle, i.e. G0/G1, S and $\mathrm{G} 2 / \mathrm{M}$, as well as of polyploïdic cells and sub-G1 cells was determined in all samples after various culture times ( $2-6$ days) apoptosis is accompanied by degradation of lamin $A+B .^{39}$ We started an immunocytochemical study of the expression of lamin B during apoptosis in our cells. Whereas treatment with RA alone resulted in extensive lamin B degradation concomitant to chromatin condensation, in the presence of RA plus Dex lamin B was only partly dissociated (data not shown).

In RPMI 8226 myeloma cells, the basal level of expression of tTG is negligible and RA treatment induces expression detectable after a few hours at the mRNA level (data not shown) and after 2 days at both the protein and enzymatic activity levels (Figures 8 and 9). The control of expression of tTG by RA is well documented in other human and animal models, ${ }^{40}$ where it appears to be transcriptional. ${ }^{41}$ Conflicting data have been reported about the type of $\mathrm{RA}$ receptors involved in this control. ${ }^{14,42}$ Whereas a retinoid response element has been identified within the mouse tTG gene promoter, ${ }^{43}$ such a responsive element has not yet been found in the human promoter sequence. ${ }^{44}$ Moreover no negative glucocorticoid element has been identified in this promoter to date, and the mechanism of the inhibition of the RA-dependent induction of tTG is still unknown. tTG is a $\mathrm{Ca}^{2+}$-dependent enzyme catalyzing the formation of $\varepsilon$-( $\gamma$-glutamyl) lysine cross-links between polypeptide chains ${ }^{45}$ and could play a role in apoptosis by cross-linking cellular proteins and preventing the release of intracellular macromolecules. ${ }^{21}$ Our observation that this enzyme accumulates in apoptotic bodies is in agreement with previous observations suggesting that this enzyme could participate in their formation. ${ }^{21}$ Overexpression of tTG in human neuroblastoma cells renders these cells highly susceptible to apoptosis suggesting a direct effect of tTG in the phenotypic maturation process leading to apoptosis. ${ }^{46}$ Interestingly, in our experiments, Dex inhibited the RA-dependent induction of tTG expression and of some of the morphological hallmarks of apoptosis (namely the apoptotic bodies), reinforcing the hypothesis that a functional link exists between the two phenomenons. The association of a lack of tTG activity and of a poorly organized apoptotic morphology in Fas-induced apoptosis in thymocytes is in agreement with this hypothesis. ${ }^{47}$ The ability of tTG to play an effector role in the apoptotic program depends on the cellular context. ${ }^{48}$ In our RPMI 8226 cells as in HL-60 leukemia cells, both tTG expression and apoptosis are induced following RA treatment, ${ }^{13,42}$ whereas in other cellular models, like NB-4 human acute promyelocytic leukemia cells, RA-dependent TTG induction may be observed without any occurrence of apoptosis. ${ }^{49}$ tTG regulation in apoptosis probably requires cooperation with other effector agents, which may be differentially expressed and controlled according to the cell type studied.

A growing attention is focused on apoptosis in multiple myeloma. It has been recently shown that apoptosis could be elicited in certain myeloma cell lines by various culture conditions, including serum starvation and treatment with antimitotic agents or with glucocorticoids, an effect prevented by interleukin-6, a major myeloma growth factor. $^{30-32}$ RA was also recently reported to interfere, in long-term culture experiments, with the IL-6 autocrine 
A

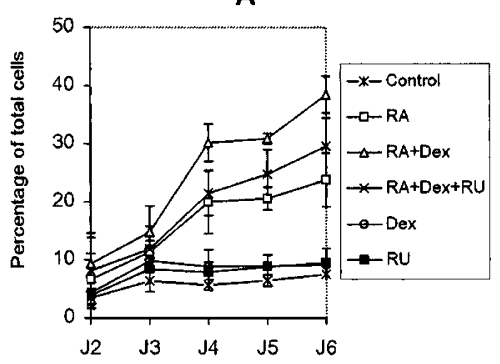

B

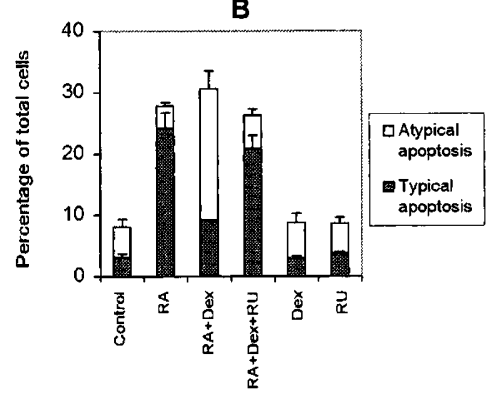

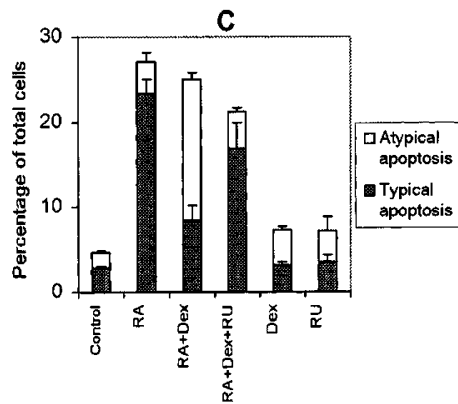

Figure 11 Kinetics of the appearance of sub-G0/G1 cells and ratio of apoptotic to necrotic cells after treatment with RA and/or Dex. Cells were cultured for 6 days with, at J0, a single pulse of each inducer ( $1 \mu \mathrm{M} \mathrm{RA}, 0.5 \mu \mathrm{M} \mathrm{Dex}, 2 \mu \mathrm{M}$ RU486) used alone or in combination. (A) Cells (percentage of total) in the sub-G0/G1 fraction measured from $\mathrm{J} 2$ to $\mathrm{J} 6$ by flow cytometry after propidium iodide staining. Quantification of typical and atypical apoptotic cells at J6 was performed after staining with May-Grünwald-Giemsa (B) and by using the TUNEL method (C). In each case, percentages were determined in triplicate counts of 400 cells

growth of the two human myeloma cell lines U266 and RPMI 8226, via induction of apoptosis. ${ }^{25}$ Beyond this cross-talk with the IL-6 pathway we are trying now to define how RA can interact with the expression of various elements of the complex network of cell death regulators. ${ }^{50,51}$

Finally, RPMI 8226 cells afford a good model to study the differential regulation of the various cytoplasmic and nuclear events occurring during apoptosis. Other cell lines should be explored in order to assess the potential relevance of the effects observed in this peculiar model to the regulation of myeloma death, in general, and the implications for myeloma therapy.

\section{Materials and Methods}

\section{Reagents}

RA, Dex (both from Sigma, St Louis, MO, USA) and RU486 (Roussel Uclaf, Romainville, France) were dissolved in absolute ethanol at $10^{-2} \mathrm{M}$ stock concentration and stored at $-20^{\circ} \mathrm{C}$ in the dark. The final ethanol concentration in culture medium was below $0.01 \%$. Camptothecin (Sigma) was dissolved in dimethylsulfoxide (DMSO) at a initial stock concentration of $3 \times 10^{-3} \mathrm{M}$ and stored at $-20^{\circ} \mathrm{C}$ in the dark.

\section{Cell lines and cell culture}

RPMI 8226 cells (human myeloma, CCL-155 American Type Culture Collection, USA) ${ }^{18,52}$ were maintained as suspension cultures in RPMI media, supplemented with Glutamax I, 10\% (v/v) heatinactivated fetal calf serum (FCS), $100 \mathrm{U} / \mathrm{ml}$ penicillin and $100 \mu \mathrm{g} / \mathrm{ml}$ streptomycin (all from Gibco-BRL, Paisley, Scotland). Cells were maintained in logarithmic growth at a cell density of about $5 \times 10^{5} \mathrm{cells} / \mathrm{ml}$. Cells mean doubling time was around $48 \mathrm{~h}$.

Cells in logarithmic phase were resuspended in culture medium (RPMI 1640 containing Glutamax I, $100 \mathrm{U} / \mathrm{ml}$ penicillin, $100 \mu \mathrm{g} / \mathrm{ml}$ streptomycin, $5 \mu \mathrm{g} / \mathrm{ml}$ insulin, $5 \mu \mathrm{g} / \mathrm{ml}$ transferrin, $5 \mathrm{ng} / \mathrm{ml}$ sodium selenite (Sigma) and supplemented with $5 \%$ FCS) at a density of $3 \times 10^{5}$ cells $/ \mathrm{ml}$ into culture flasks protected from light. Cells were treated with $10^{-6} \mathrm{M} \mathrm{RA}, 0.5 \times 10^{-5} \mathrm{M}$ Dex, $2 \times 10^{-6} \mathrm{M} \mathrm{RU486}$, alone or combined, or with vehicle only. After $48 \mathrm{~h}$ of contact, the medium was adjusted to $10 \%$ FCS and cells were diluted daily to maintain a concentration of $5 \times 10^{5}$ cells $/ \mathrm{ml}$ for 6 days.

\section{Proliferation assays}

$\left[{ }^{3}\right.$ H]thymidine incorporation assay After $48 \mathrm{~h}$ treatment, $0.25 \mathrm{ml}$ cell samples $\left(2 \times 10^{5} \mathrm{cells} / \mathrm{ml}\right)$ resuspended in complete medium were distributed in 24 -well plates. $\left[{ }^{3} \mathrm{H}\right]$ thymidine $(20 \mathrm{Ci} / \mathrm{mmol}$, Amersham, UK) was then added at $1 \mu \mathrm{Ci} /$ well for $3 \mathrm{~h}$. Cells were washed twice with ice cold Earle's medium (Gibco-BRL) and incubated overnight at $4{ }^{\circ} \mathrm{C}$ with $50 \mu$ l of lysis buffer ( $20 \mathrm{mM}$ Tris- $\mathrm{HCl}, \mathrm{pH} 7.4,100 \mathrm{mM} \mathrm{NaCl}$, $10 \mathrm{mM}$ EDTA). $1 \mathrm{~N} \mathrm{NaOH}$ was added to the lysate. Incubation proceeded for $1 \mathrm{~h}$ at $4^{\circ} \mathrm{C}$ then the lysate was neutralized by $50 \mu \mathrm{l} \mathrm{HCl}$. Proteins and DNA were precipitated by $5 \%$ TCA $\left(4^{\circ} \mathrm{C}, 30 \mathrm{~min}\right)$ and collected over a GF/C (Whatman, Paris, France) glass fiber filter. Thymidine incorporation was assayed by scintillation counting of the GF/C filters (average thymidine incorporation in untreated cells was usually 8600 c.p.m./well).

Ki-67 detection by indirect immunocytochemistry Percentage of Ki67 positive cells was evaluated after $2-5$ days of treatment. Cells spread on glass slides were washed three times with $1 \times$ PBS, fixed by cold-acetone (buffered at pH 7.6) and by absolute cold-acetone (each for $2 \mathrm{~min}$ at $-20^{\circ} \mathrm{C}$ ). After drying for $10 \mathrm{~min}$ at room temperature, cells were fixed again with $4 \%$ paraformaldehyde (Merck) in $1 \times$ PBS for $2 \mathrm{~min}$, permeabilized in $0.1 \%$ Triton X-100 in $1 \times$ PBS for 5 min and then incubated with reagents diluted in $1 \times$ PBS- $3 \%$ BSA. Cells were labeled with successive layers of mouse monoclonal IgG anti-Ki-67 (MIB 1, Immunotech, Marseille, France) and avidin/biotinylated enzyme complex (Vectastain Elite-ABC Peroxidase kit, Vector laboratories, INC, USA). DAB (Sigma) was used as the peroxidase substrate. Cells were stained with diluted Giemsa.

\section{Morphological studies}

Cell viability was determined using the trypan blue exclusion test. Cells were counted with a Malassez hemocytometer over the 6 days treatment (living and apoptotic cells excluded trypan blue).

After the appropriate time of treatment, $10^{5}$ cells were centrifuged on glass slides (Cytospin 3, Shandon, Cergy Pontoise, France), airdried for at least $2 \mathrm{~h}$ and stored at $-20^{\circ} \mathrm{C}$. Cells were stained with MGG. DNA staining with Hoechst 33258 [Bis (benzidine)] (Sigma) was performed as described by Galli and Fratelli. ${ }^{53}$ Briefly, cells were fixed by Carnoy solution (methanol:acetic acid, $3: 1, \mathrm{v} / \mathrm{v}$ ), stained with Hoechst $33258\left(0.1 \mu \mathrm{g} / \mathrm{ml}\right.$ in $1 \times$ PBS for $10 \mathrm{~min}$ at $\left.37^{\circ} \mathrm{C}\right)$, washed with tap water for $5 \mathrm{~min}$, air-dried and mounted with DABCO-glycerol (1,4-diazabicyclo(2,2,2)octane, Aldrich, Milwaukee, WI, USA). Cells were observed using an Olympus $\mathrm{BH}$ fluorescence microscope 
(excitation wavelength: $365 \mathrm{~nm}$ ). The number of apoptotic cells was determined after counting at least 2000 cells.

Apoptotic cells were identified upon the following morphological features: ${ }^{35}$ cells displaying chromatin condensation, nuclear disintegration, vacuole formation and membrane blebbing were identified as apoptotic. By contrast, cells with cytoplasmic swelling, membrane disruption and disappearance of nuclear chromatin or distribution of the nuclear chromatin in small ill-defined particles, could be early classified as lysed.

\section{DNA fragmentation analysis}

Total genomic DNA was isolated from $2.5 \times 10^{6}$ cells using the method described by Eldadah et al. ${ }^{54}$ Briefly, the cells treated or not were collected by centrifugation at day 5 , washed once with PBS and lysed by $2 \mathrm{ml}$ of $7 \mathrm{M}$ guanidinium hydrochloride. The lysate was added to $1 \mathrm{ml}$ of Wizard Minipreps DNA Purification Resin (Promega), gently mixed and centrifuged at $2000 \times g$ for $5 \mathrm{~min}$. The pellets were resuspended in $3 \mathrm{ml}$ of the following solution: $90 \mathrm{mM} \mathrm{NaCl}, 9 \mathrm{mM}$ Tris- $\mathrm{HCl} \mathrm{pH} \mathrm{7.4,2.25} \mathrm{mM}$ EDTA, $55 \%$ ethanol, and transferred to Wizard Minicolumns (Promega). The columns were washed with $2 \times 3 \mathrm{ml}$ of the same solution and centrifuged over microfuge tubes at $5000 \times g$ for $5 \mathrm{~min}$. DNA was eluted by $50 \mu \mathrm{l}$ TE buffer $\mathrm{pH} 8.0$ and residual RNA was eliminated by incubation with RNAse A at $37^{\circ} \mathrm{C}$ for $30 \mathrm{~min}$.

The DNA obtained was of high purity, with a $260: 280 \mathrm{~nm}$ ratio of 1.8-2.0. It was used in a LM-PCR assay (Ligation Mediated Polymerase Chain Reaction), ${ }^{20}$ according to the manufacturer's instructions (Clontech Laboratories, Palo Alto, CA, USA). This method allows to reveal genomic DNA ladders that may be undetectable by other methods. DNA electrophoresis (10 $\mathrm{ng} / \mathrm{lane})$ was run through $1.2 \%$ agarose $/ \mathrm{EtBr}$ gel at $6 \mathrm{~V} / \mathrm{cm}$ for approximately $2.5 \mathrm{~h}$. Because of the addition of the LM-PCR adaptors (48 bp total) the bands are slightly larger than those of a conventional ladder.

\section{Quantification of DNA fragmentation}

Solubilized DNA was quantified by the diphenylamine assay as described by Bansal et al. ${ }^{55}$ Treated and untreated cells $\left(2 \times 10^{7}\right)$ were harvested, washed at $4^{\circ} \mathrm{C}$ in $1 \times$ PBS and lysed for 30 min at $4^{\circ} \mathrm{C}$ in $5 \mathrm{mM}$ Tris/HCl pH 8.0, $20 \mathrm{mM}$ EDTA buffer containing 0.5\% Triton $\mathrm{X}$ 100. Lysates were centrifuged at $27000 \times g$ for $20 \mathrm{~min}$ to separate low molecular weight DNA (supernatant) from intact chromatin (pellet). Pellet and supernatants were resuspended in $500 \mu \mathrm{l}$ of lysis buffer supplemented with $2 \mathrm{mg} / \mathrm{ml} \mathrm{BSA}$. After adding $1 \mathrm{ml} 10 \%$ trichloroacetic acid (TCA), and incubation for $20 \mathrm{~min}$ at $4^{\circ} \mathrm{C}$, samples were centrifuged for $5 \mathrm{~min}$ at $10000 \times \mathrm{g}$. Pellets were resuspended in $1 \mathrm{ml}$ $100 \%$ ethanol at $4{ }^{\circ} \mathrm{C}$ and incubated overnight at $-20^{\circ} \mathrm{C}$. After centrifugation at $18000 \times g$ for $30 \mathrm{~min}$, RNA was hydrolysed in $1 \mathrm{~N}$ $\mathrm{NaOH}$ at $37^{\circ} \mathrm{C}$ for $1 \mathrm{~h}$. Reaction mixtures were incubated for $15 \mathrm{~min}$ on ice, brought to $10 \% \operatorname{TCA}\left(30 \mathrm{~min}\right.$ at $4{ }^{\circ} \mathrm{C}$ ) and centrifuged at $4{ }^{\circ} \mathrm{C}$ for $10 \mathrm{~min}$ at $8000 \times \mathrm{g}$. Pellets were resuspended in $1 \mathrm{ml}$ of $5 \%$ perchloric acid for $15 \mathrm{~min}$ at $90^{\circ} \mathrm{C}$ and frequently mixed. Samples were centrifuged for $20 \mathrm{~min}$ at $900 \times \mathrm{g}$ at $4^{\circ} \mathrm{C}$ and supernatants were treated overnight at $37^{\circ} \mathrm{C}$ with $2 \mathrm{ml}$ Burton's reagent. ${ }^{56} \mathrm{OD}_{600}$ of each sample was assayed and the DNA amount found in supernatants was expressed as the percentage of total DNA from $2 \times 10^{7}$ cells.

\section{TUNEL technique}

In situ nuclear DNA fragmentation was measured according to a method based on $3^{\prime} \mathrm{OH}$ end labeling of DNA breaks with deoxyuridine terminal deoxynucleotidyl transferase (TdT), ${ }^{57}$ with minor modifications. Treated or untreated cells were spread on glass slides, rehydrated with $1 \times$ PBS for $5 \mathrm{~min}$, fixed with $1 \%$ paraformaldehyde $(\mathrm{pH} 7.4)$ (Merck, Darmstadt, Germany) for 15 min at $4^{\circ} \mathrm{C}$, and washed twice with $1 \times$ PBS. The TUNEL reaction was carried out by incubating cells for $1 \mathrm{~h}$ at $37^{\circ} \mathrm{C}$ in a moist chamber with $1 \mathrm{nmol} / \mu \mathrm{l} \mathrm{FITC-12-dUTP} \mathrm{(Boehringer}$ Mannheim), $25 \mathrm{mM} \mathrm{CoCl}_{2}, 25 \mathrm{U} / \mu \mathrm{l} \mathrm{TdT}$ (Boehringer Mannheim) and TdT buffer (125 mM Tris- $\mathrm{HCl}, 1 \mathrm{M}$ potassium cacodylate, $1.25 \mathrm{mg} / \mathrm{ml}$ $\mathrm{BSA}, \mathrm{pH}$ 6.6). Cells were then washed twice with ice-cold $1 \times \mathrm{PBS}$, stained with Evans blue and mounted with DABCO-glycerol. Fluorescence was observed using the fluorescence microscope.

\section{Tissue transglutaminase}

Immunofluorescence staining Treated or untreated cells were processed on slides as described by Collard et $a^{F^{8}}$ and incubated with the primary antibody, a specific mouse monoclonal anti-tTG IgG raised against purified guinea pig enzyme ${ }^{59}$ (generous gift from $\mathrm{Dr} P$. Birckbichler, Ardmore, Oklahoma, USA). The secondary antibody was fluorescein-conjugated sheep anti-mouse $\operatorname{lgG}$, used at a dilution of $1 /$ 1000 (Biosys, Compiègne, France). Slides were observed using the fluorescence microscope.

Activity assay tTG activity of cell lysates was assayed by $\mathrm{Ca}^{2+}$. dependent incorporation of $\left[{ }^{3} \mathrm{H}\right]$ putrescine into $\mathrm{N}, \mathrm{N}^{\prime}$ dimethylated casein. ${ }^{60} 1 \times 10^{7}$ treated or untreated cells were harvested, washed twice with $1 \times$ PBS and lysed in ice cold lysis buffer $(20 \mathrm{mM}$ Tris/ $\mathrm{HCl}$, $\mathrm{pH} 7.5,1 \mathrm{mM}$ EDTA, $0.5 \%$ Triton $\mathrm{X}-100$ for $30 \mathrm{~min}$. $0.2 \mathrm{mg}$ protein were incubated at $30^{\circ} \mathrm{C}$ for $20 \mathrm{~min}$ in a total volume of $100 \mu \mathrm{l}$ containing $20 \mathrm{mM}$ Tris- $\mathrm{HCl} \mathrm{pH} 7.5,5 \mathrm{mM} \mathrm{CaCl}_{2}, 10 \mathrm{mM} \mathrm{b}-$ mercaptoethanol, $2 \mathrm{mg} / \mathrm{ml} \mathrm{N}, \mathrm{N}^{\prime}$ dimethylated casein, $2 \mu \mathrm{Ci}$ $\left[{ }^{3} \mathrm{H}\right]$ putrescine $(30-60 \mathrm{Ci} / \mathrm{mmol}$, Dupont-NEN), $0.2 \mathrm{mM}$ putrescine. Aliquots were spotted on Whatman 3 MM filter paper, fixed in 10\% TCA and then sequentially washed in 5\% TCA, ethanol/acetone (v/v) and acetone. Protein-bound $\left[{ }^{3} \mathrm{H}\right]$ putrescine was determined by liquid scintillation counting of the filters. Background value was obtained by substitution of $1 \mathrm{mM}$ EGTA for $\mathrm{CaCl}_{2}$ in the reaction mixture. Enzyme activity was expressed in picomoles of $\left[{ }^{3} \mathrm{H}\right]$ putrescine incorporated into $\mathrm{N}, \mathrm{N}^{\prime}$ dimethylated casein per minute and per milligram of protein. Protein concentration was assayed by the Bradford method ${ }^{61}$ using fraction V Albumin (Boehringer Mannheim) as a standard.

\section{Cell cycle analysis and flow cytometric detection of apoptosis}

$10^{6}$ cells were collected in triplicate by centrifugation from treated and control cultures, washed once with PBS, fixed in $70 \%$ cold ethanol and stored at $-20^{\circ} \mathrm{C}$. On the day of analysis, after washing with PBS, cells were treated with $5 \mathrm{U} / \mathrm{ml}$ RNAse A (DNAse-free, Promega) for $15 \mathrm{~min}$ at room temperature. They were then incubated for $30 \mathrm{~min}$ in the dark with $50 \mu \mathrm{g} / \mathrm{ml}$ propidium iodide (Sigma Chemical, St Louis, MO, USA) containing $0.01 \%$ Triton $\mathrm{X}-100$. DNA content was analyzed immediately using a Coulter (Hileah, FL, USA) EPICS ELITE flow cytometer. Upon acquisition of 20000 events, the percentage of cells in the different phases of the cell cycle was determined, using the Multicycle analysis software (Coulter). Apoptosis was also quantified: the hypodiploïd region $(<2 n)$ was identified as apoptotic cells and appeared as a distinct sub-G0/G1 peak.

\section{Acknowledgements}

This work was supported by grants from Université de Lille II, INSERM, Association de la Recherche contre le Cancer, Comité du Pas-de-Calais 
de la Ligue Nationale Contre le Cancer. All the groups involved in this work belong to and are supported by IFR 22 (INSERM, $\mathrm{CH}$ et $\mathrm{U}$, Université de Lille II and Centre Oscar Lambret). We are indebted to B. Masselot and M. Tual for skilful technical assistance and to B. Joseph and P. Lefebvre for helpful discussion.

\section{References}

1. Greipp PR (1992) Advances in the diagnosis and management of myeloma. Semin. Hematol. 29: 24-25

2. Gudas LJ, Sporn MB and Roberts AB (1994) Cellular biology and biochemistry of retinoids, In The retinoids: Biology, Chemistry, and Medicine. 2nd edn. Sporn MB, Roberts AB and Goodman DS (eds) Raven Press Ltd: New York. pp. 443520

3. Hofman C and Eichele G (1994) Retinoids in development. In The retinoids: Biology, Chemistry, and Medicine. 2nd edn. Sporn MB, Roberts AB and Goodman DS (eds) Raven Press Ltd: New York. pp. 387-442

4. Smith MA, Parkinson DR, Cheson BD and Friedman MA (1992) Retinoids in cancer therapy. J. Clin. Oncol. 10: 839-864

5. Hong WK and Itri LM (1994) Retinoids and human cancer. In The retinoids: Biology, Chemistry, and Medecine. 2nd edn. Sporn MB, Roberts AB, Goodman DS (eds) Raven Press Ltd: New York. pp. 597-630

6. Sidell N, Taga T, Hirano T, Kishimoto T and Saxon A (1991) Retinoic acidinduced growth inhibition of a human myeloma cell line via down-regulation of IL6 receptors. J. Immunol. 146: 3809-3814

7. Ogata A, Nishimoto N, Shima Y, Yoshizaki K and Kishimoto T (1994) Inhibitory effect of all-trans retinoic acid on the growth of freshly isolated myeloma cells via interference with interleukine-6 signal transduction. Blood 84: 3040-3046

8. Siegel D, Niesvizky R, MillerWH, Busquets X, Kumar Rand Mickaeli J (1992) Alltrans retinoic (ATRA) and interferon a (IFNa) synergistically inhibit myeloma cell growth and induce retinoic acid receptor a (RARa) expression. Blood 80 suppl:121a (Abstract)

9. Thompson CB (1995) Apoptosis in the pathogenesis and treatment of disease. Science 267: $1456-1462$

10. Lotan R (1980) Effects of vitamin A and its analogs (retinoids) on normal and neoplastic cells. Biochem. Biophys. Acta 605: 33-91

11. Martin SJ, Bradley JG and Cotter TG (1990) HL-60 cells induced to differentiate towards neutrophils subsequently die via apoptosis. Clin. Exp. Immunol. 79: $448-453$

12. Piacentini M, Fesus L, Farrace MG, Ghibelli L, Piredda Land Melino G(1991) The expression of 'tissue' transglutaminase in two human cancer cell lines is related with the programmed cell death (apoptosis). Europ. J. Cell Biol. 54: 246-254

13. Nagy L, Thomazy VA, Shipley G, Fésüs L, Lamph W, Heyman RA, Chandraratna RAS and Davies PJA (1995) Activation of retinoid X receptors induces apoptosis in HL-60 cell lines. Mol. Cell Biol. 15: 3540-3551

14. Zhang LX, Mills KJ, Dawson MI, Collins SJ and Jetten AM (1995) Evidence for the involvement of retinoic acid receptor RARa-dependent signaling pathway in the induction of tissue transglutaminase and apoptosis by retinoids. J. Biol. Chem. 270: $6022-6029$

15. Alexanian R, Dimopoulos MA, Delasalle K and Barlogie B (1992) Primary dexamethasone treatment of multiple myeloma. Blood 80: 887-890

16. Gomi M, Moriwaki K, Katagiri S, Kurata Y and Thompson EB (1990) Glucocorticoid effects on myeloma cells in culture: Corrrelation of growth inhibition with induction of glucocorticoid receptor messenger RNA. Cancer Res. 50: $1873-1878$

17. Ishikawa H, Tanaka H, Iwito K, Tanabe O, Asaoku H, Bobuyoshi M, Yamamoto I, Kawano M and Kuramuto A (1990) Effect of glucocorticoids on the biologic activities of myeloma cells: Inhibition of interleukin-1b osteoclast activating factor-induced bone resorbtion. Blood 75: 715-720

18. Moore GE and Kitamura $H$ (1968) Cell line derived from a patient with myeloma. New York State J. Med. 68: 2054-2060

19. Seignerin D and Guillaud $P$ (1991) L'antigène Ki-67, marqueur du cycle cellulaire et de la prolifération tumorale. Pathologie Biologie 39: 1020-1028

20. Staley K, Blaschke AJ and Chun J (1997) Apoptotic DNA fragmentation is detected by a semiquantitative ligation-mediated PCR of blunt DNA ends. Cell Death Diff. 4: 66-75
21. Fésüs L, Thomazy V and Falus A (1987) Induction and activation of tissue transglutaminase during programmed cell death. FEBS Lett. 224: 104-108

22. Mangiarotti R, Danova M, Alberici R and Pellicciari C (1998) All-trans retinoic acid (ATRA)-induced apoptosis is preceded by $\mathrm{G} 1$ arrest in human MCF-7 breast cancer cells. Br. J. Cancer 77: 186-191

23. Koskela K, Neva M, Remes K, Pelliniemi TT and Pulkki K (1994) Inhibition of interleukine-6 receptor (IL-6R) secreting human myeloma cell proliferation by alltrans retinoic acid (ATRA) and alpha-interferon (a-IFN). Blood 84: $175 a$ (Abstract)

24. Taetle R, Dos Santos B, Akamatsu K, Koishihara Y and Ohsugi Y (1995) Effects of all-trans retinoic acid and anti-growth factor receptor antibodies on growth and programmed cell death of human myeloma cells. Blood 86: 189a(Abstract)

25. Levy Y, Labaume S, Colombel M and Brouet JC (1996) Retinoic acid modulates the in vivo and in vitro growth of IL-6 autocrine human myeloma cell lines via induction of apoptosis. Clin. Exp. Immunol. 104: 167-172

26. Chen YH, Desai P, Shiao RT, Lavelle D, Haleem A and Chen J (1996) Inhibition of myeloma cell growth by dexamethasone and all-trans retinoic acid: synergy through modulation of interleukine-6 autocrine loop at multiple sites. Blood 87: $314-323$

27. Esquenet M, Swinnen JV, Heyns W and Verhoeven G (1997) LNCaP prostatic adenocarcinoma cells derived from low and high passage numbers display divergent responses not only to androgens by also to retinoids. J. Steroid Biochem. Molec. Biol. 62: 391-399

28. Leid $M$, Kastner $P$ and Chambon $P$ (1992) Multiplicity generates diversity in the retinoic acid signalling pathways. TIBS 17: 427-433

29. Joseph B, Lefebvre O, Mereau-Richard C, Danzé PM, Belin-Plancot MT and Formstecher $P$ (1998) Evidence for the involvement of both retinoic acid receptor-and retinoic $X$ receptor-dependent signaling pathways in the induction of tissue transglutaminase and apoptosis in the human myeloma cell line RPMI 8226. Blood 91: 2423-2432

30. Shiao RT, Miglietta L, Khera SY, Wolfson A and Freter CE (1995) Dexamethasone and suramin inhibit cell proliferation and interleukine-6mediated immunoglobulin secretion in human lymphoid and multiple myeloma cell lines. Leukemia Lymphoma 17: 485-494

31. Lichtenstein A, Tu Y, Fady C, Vescio R and Berenson J (1995) Interleukin-6 inhibits apoptosis of malignant plasma cells. Cell. Immunol. 162: 248-255

32. Hardin J, MacLeod S, Grigorieva I, Chang R, Barlogie B, Xiao H and Epstein J (1994) Interleukin-6 prevents dexamethasone-induced myeloma cell death. Blood 84: 3063-3070

33. Moalli PA, Pillay S, Weiner D, Leikin R and Rosen ST (1992) A mechanism of resistance to glucocorticoids in multiple myeloma: Transient expression of a truncated glucocorticoid receptor mRNA. Blood 79: 213-222

34. Moalli PA, Pillay S, Krett NL and Rosen ST (1993) Alternatively spliced glucocorticoid receptor messenger RNAs in glucocorticoid-resistant human multiple myeloma cells. Cancer Res. 53: 3877-3879

35. Arends MJ and Wyllie AH (1991) Apoptosis: Mechanisms and roles in pathology. Int. Rev. Exp. Pathol. 32: 223-254

36. Falcieri E, Zamai L, Santi S, Cinti C, Gobbi P, Bosco D, Cataldi A, Betts C and Vitale M (1994) The behaviour of nuclear domains in the course of apoptosis. Histochemistry 102: 221-231

37. Oberhammer F, Fritsch G, Schmied M, Pavelka M, Printz D, Purchio T, Lassmann $\mathrm{H}$ and Schulte-Hermann R (1993) Condensation of the chromatin at the membrane of an apoptotic nucleus is not associated with activation of an endonuclease. J. Cell Sci. 104: 317-326

38. Bortner CD, Oldenburg NBE and Cidlowski JA (1995) The role of DNA fragmentation in apoptosis. Trends Cell Biol. 5: 21-26

39. Oberhammer F, Hochegger $K$ and Froschi G (1994) Chromatin condensation during apoptosis is accompanied by degradation of lamin $A+B$ without activation of cdc2 kinase. J. Cell Biol. 126: 827-883

40. Aeschilimann D and Paulsson M (1994) Transglutaminases Protein crosslinking enzymes in tissues and body fluids. Thrombosis Haemostasis 71: $402-$ 415.

41. Chiocca EA, Davies PJA and Stein JP (1988) The molecular basis of retinoic acid action. J. Biol. Chem. 263: 11584-11589

42. Boehm MF, Zhang L, Zhi L, McClurg MR, Berger E, Wagoner M, Mais DE, Suto CM, Davies PJA, Heyman RA and Nadzan AM (1995) Design and synthesis of potent retinoid $X$ receptor selective ligands that induce apoptosis in leukemia cells. J. Med. Chem. 38: 3246-3155. 
43. Nagy L, Saydak M, Shipley N, Lu S, Basilion JP, Yan ZH, Syka P, Chandraratna RAS, Stein JP, Heyman RA and Davies PJA (1996) Identification and characterization of a versatile retinoid response element (retinoic acid receptor response element-retinoid $X$ receptor response element) in the mouse tissue transglutaminase gene promoter. J. Biol. Chem. 271: 4355-4365

44. Lu S, Saydak M. Gentile V, Stein JP and Davies PJA (1995) Isolation and characterization of the human tissue transglutaminase gene promoter. J. Biol. Chem. 270: $9748-9756$

45. Folk JE (1980) Transglutaminases. Annu. Rev. Biochem. 49: 517-531

46. Melino G, Annicchiarico-Petruzzelli M,PireddaL, Candi E, GentileV, Davies PJA and Piacentini M (1994) Tissue transglutaminase and apoptosis: Sense and antisense transfection studies with human neuroblastoma cells. Mol. Cell Biol. 14: $6584-6596$

47. Szondy Z, Molnar P, Nemes Z, Boyiadzis M, Kedei N, Toth R and Fésüs L (1997) Differential expression of tissue transglutaminase during in vivo apoptosis of thymocytes induced via distinct signalling pathways. FEBS Lett. 404: $307-313$

48. Piacentini M (1995) Tissue transglutaminase: A candidate effector element of physiological cell death. Curr. Top. Microbiol. Immunol. 200: 163-175

49. Benedetti L, Grignani F, Scicchitano BM, Jetten AM, Diverio D, Lo Coco F, Avvisati G, Gambacorti-Passerini C, Adamo S, Levin AA, Pelicci Pg and Nervi C (1996) Retinoid-induced differentiation of acute promyelocytic leukemia involves PML-RARa-mediated increase of type II transglutaminase. Blood 87: $1939-1950$

50. Hoffman B and Liebermann DA (1994) Molecular controls of apoptosis: differentiation/growth arrest primary response genes, proto-oncogenes, and tumor suppressor genes as positive and negative modulators. Oncogene 9 : 1807-1812

51. Korsmeyer SJ (1995) Regulators of cell death. Trends Genet. 11: 101-105
52. Moore GE, Marbell JW, Woods LK, Morgan RT and Semple TU (1982) RPMI 8226, a human myeloma cell line: an update. Cancer Res. 33: 126

53. Galli $G$ and Fratelli M (1993) Activation of apoptosis by serum deprivation in a teratocarcinoma cell line: inhibition by L-acetylcarnitine. Exp. Cell Res. 204:54 60

54. Eldadah BA, Yakovlev AG and Faden AI (1996) A new approach for the electrophoretic detection of apoptosis. Nucleic Acids Res. 24: $4092-4093$

55. Bansal N, Houle A and Melnykouych G (1991) Apoptosis: mode of cell death induced in T cell leukemia lines: dexamethasone and other agents. Faseb J. 5: $211-216$

56. Burton K (1956) A study of the conditions of the diphenylamine reaction for the colorimetric estimation of DNA. Biochem J. 62: 315-323

57. Gavriely Y, Sherman Y and Ben-Sasson SA (1992) Identification of programmed cell death in situ via specific labeling of nuclear DNA fragmentation. J. Cell Biol. 119: 493-501

58. Collard JF, Senecal JL and Raymond Y (1992) Redistribution of nuclear lamin A is an early event associated with differentiation of human promyelocytic leukemia HL-60 cells. J. Cell Sci. 101: 657-670

59. BirckbichlerPJ, Upchurch HF, Patterson MKand Conway E (1985) A monoclonal antibody to cellular transglutaminase. Hybridoma 4: 179-186

60. Lorand L, Campbell-Wilkes LK and Cooperstein L (1972) A filter paper assay for transamidating enzymes using radioactive amine substrates. Anal. Biochem. 50: $623-631$

61. Bradford MM (1976) A rapid and sensitive method for the quantification of microgram quantities of protein utilizing the principle of protein-dye binding. Anal. Biochem. 72: $248-254$ 